\title{
Challenges of Distance/Online and Face-to-Face Education in the New Normal: Experiences of Reggio Emilia-Inspired Early Childhood Educators in Turkey
}

\author{
Hatice Zeynep Inan ${ }^{1 *}$
}

${ }^{1}$ Bursa Uludag University, TURKEY

*Corresponding Author: zeynepinan@uludag.edu.tr

Citation: Inan, H. Z. (2021). Challenges of Distance/Online and Face-to-Face Education in the New Normal: Experiences of Reggio Emilia-Inspired Early Childhood Educators in Turkey. Pedagogical Research, 6(1), em0086. https://doi.org/10.29333/pr/9304

\begin{abstract}
ARTICLE INFO
Received: 4 Oct. 2020

Accepted: 25 Nov. 2020

ABSTRACT

The current study aimed to examine the perceptions and experiences of Reggio Emilia-inspired early childhood educators in Turkey regarding the difficulties they experienced in the New Normal. The study utilized the method of phenomenography. Data collection included an online questionnaire consisting of open-ended questions and demographic information questions. Data analysis included both the content analysis and the thematic analysis. The study involved 226 Reggio Emilia-inspired educators from different schools in Turkey. The findings showed that many of the participants were not aware of different ways to do distance education and adhered to online education only. Most of those educators, who adhered to online education, complained about difficulties and negative experiences related to online education and they thought that online/distance education is suitable for children aged 6 and up but not for younger ones. Only a few of them agreed that online education was effective in supporting children's development and learning. On the other hand, all of them agreed that face-to-face education was effective during the pandemic. The findings of the current research also showed that some educators received both parents' support and others' support (e.g., own relatives, managers, colleagues) but some of them received no support at all during the pandemic.
\end{abstract}

Keywords: early childhood education, preschool, COVID-19, Reggio Emilia, phenomenography

\section{INTRODUCTION}

Reggio Emilia approach, born in Italy, is one of the contemporary alternative early childhood education models in the world, and the number of schools inspired by this approach in Turkey is increasing rapidly. Reggio Emilia education is about conducting exploration and investigation in the environment, doing a project work at least in pairs, being a community of learning while learning, using various languages like visual arts to be able to communicate effectively. All of those activities need to be done hands-on and collectively but it might be difficult to accomplish them virtually or face-to-face in the New Normal. Accordingly, Reggio Emilia-inspired teachers in Turkey might be having difficulties in conducting online/distance education or face-to-face education while following the hygiene/social distance rules during the COVID-19 pandemic. The current study aimed to examine the perceptions and experiences of Reggio Emilia-inspired early childhood educators in Turkey regarding the difficulties they experienced in the New Normal.

\section{THEORETICAL BACKGROUND OF THE RESEARCH}

At beginning of the pandemic in March 2020, the government locked all of the early childhood education centers down in Turkey and declared for distance education until June 2020. As seen in Distance Learning Model adapted from Coldeway's (1986) Quadrants, there are four distinct ways to conduct distance education, i.e. students and the teacher are in the same place at the same time, students and the teacher are in the same place at different times, students and the teacher are in different places at the same time, and students and the teacher are in different places at different times (Figure 1). However, the schools were not ready for such an emergency in Turkey regarding conducting distance education, neither were Reggio Emilia-inspired preschools in Turkey. 


\begin{tabular}{|c|c|c|}
\hline DIFFERENT TIME & Different Time \& Same Place & Different Time \& Different Place \\
\hline SAME TIME & Same Time \& Same Place & Same Time \& Different Place \\
\hline & SAME PLACE & DIFFERENT PLACE \\
\hline
\end{tabular}

Figure 1. Distance Learning Model adapted from Coldeway's (1986) Quadrants

Not only Reggio Emilia-inspired educators in Turkey but also many other preschool educators around the world have experienced various problems in the New Normal and sought solutions as cited by researchers (e.g., Allvin, 2020; Cockcroft, 2020; Ferdig et al., 2020; Fraga, 2020; Mutton, 2020; OMEP, 2020; Pawilen, 2020; Varea \& González-Calvo, 2020; Wasmuth, 2020). For example, the countries in the European Union were not ready for such an emergency and declared, "Seventy-one (71.0\%) of union respondents reported that students were being taught via online platforms. However, some member organizations indicated that when schools closed there had been no systems in place for online learning and little existing content for distance learning, making the transition to this mode of education a challenge." (El Survey Report, 2020, p. 17). Scottish Government Learning Directorate (2020) also stressed the importance of physical distancing in early learning and childcare settings and kept children away from schools at first, but then was afraid about staying behind in the education of young children. It can be said that many countries did not know how to conduct comprehensive distance education and face-to-face education following the hygiene/social distancing rules during the COVID-19 pandemic.

McClain Terrell (2020), the president of NAEYC, states that two things became critical during the pandemic: The practices of self-care and self-reflection. That means nobody knew what to do at that time and they came up with their own solutions on both distance and face-to-face education. Similarly, educators and parents, all in Turkey, became an initiator and made decisions on the education of young children by themselves because nobody knew anything at that time. As if there was a consensus, many educators all around the world closed the schools and started doing distance/online education. Moreover, not only educators but also some other professionals, who were responsible for the education of young children, started doing online education for young children. For example, the staff in Denver Public Library and Brooklyn Public Library started doing programs online for young children, like doing live-music and reading books online (Cockcroft, 2020).

About such consensus, Mutua and Ong'ong'a (2020) blame the media and state, "The media play an essential role in providing information at the initial stages of a disease outbreak." (p. 7). They state that the media controlled what people believe and how they behave. As stated by Louis-Jean and Cenat (2020), the COVID-19 pandemic altered education across the World and the severity of the virus forced people to confine to homes to slow down the spread of the coronavirus, to keep social distancing and practicing coughing/sneezing etiquette, and to find ways to continue on education. Louis-Jean and Cenat (2020) state, "This could intrinsically require educators to work with educational technology companies to figure out and develop the best instructional designs to make the best out of e-learning." (p. 3). Similarly, Tria (2020), a researcher in Philippines, state, "Future studies are recommended such as planning and implementation strategy, assessing online learning systems to schools, a survey on online platforms, project proposals and capstone projects, program creation, community assessment, revision of curricula, development of instructional materials and many more." (p. 3). It is clear that actions need to be taken on education practices.

Although there was a general tendency to do online/distance education all around the world, there were local and cultural differences among practices of educators and the difficulties they had. Pramling-Samuelsson, Wagner, and Eriksen (2020) conducted research in three different countries, namely Sweden, Norway, and the United States, and stated, "The conversations reveal culturally situated similarities of early childhood educational practices but also differences across contexts. Teachers report on the challenges of their experiences but also benefits for their practice and how they engage with children and their families." (p. 129). Even when schools were started to open gradually across the world, nothing was the same regarding the face-to-face education in the New Normal. Accordingly, it became essential for us to conduct the current research for Turkey and explore early childhood educational practices and difficulties that Reggio Emilia-inspired educators experienced in Turkey.

\section{AIM OF THE RESEARCH}

The current study aimed to explore and examine early childhood educational practices and difficulties that Reggio Emiliainspired educators had in Turkey during the pandemic. Based on the findings, the current study also aimed to develop suggestions for the training of educators in the New Normal. Thus educators working in Reggio Emilia inspired schools can be offered a training package, and they can reconstruct their understanding and practices about early childhood education in the New Normal. In line with this purpose, the following goal was determined:

Understanding the challenges of distance/online and face-to-face education in the New Normal by examining perceptions and experiences of Reggio Emilia-inspired early childhood educators in Turkey from March through September 2020.

\section{METHODOLOGY}

This section presents participants, data collection, and data analysis methods of the current research.

Since it was needed to obtain rich data and focused-information on what Reggio Emilia-inspired educators experienced during the pandemic, the current study opted to utilize one of the qualitative research methods, namely phenomenography. As stated by 
Billsberry, Ambrosini, Garrido-Lopez, and Stiles (2019), phenomenography is about understanding how participants make sense of particular phenomena. Since the research method of phenomenography aimed to find out what is in people's minds, it helped the researcher in the current study understand Reggio Emilia-inspired educators' view of difficulties experienced in the distance and face-to-face education during the pandemic. The current research is an empiric study that aimed to focus on experiences and perceptions of educators about the phenomenon. Accordingly, phenomenography was a perfect method for the current study focusing on experiences and perceptions of educators and their ways of defining the selected phenomena (Marton 1994; Webb, 1997).

\section{DATA COLLECTION}

An online questionnaire was used to collect data under the method of phenomenography. Since the current research aimed to identify the problems Reggio Emilia-inspired educators experience in distance/online and face-to-face education during the COVID-19 pandemic, the questionnaire consisted of open-ended questions like "What is your experience of particular phenomena?" and demographic information questions, which provided an important information about the profile of Reggio Emilia-inspired educators participated in the study. Data collection lasted for two weeks.

\section{DATA ANALYSIS}

The data were analyzed through the content and thematic analyses, which are prevalent tools of qualitative research studies. As consistent with the thematic analysis, the open-ended survey recordings were listed first and then the lists were analyzed comparatively and cumulatively. The meanings driven from the data were labeled and then categorized, and finally, each category was supported with excerpts from the data as evidence. To be able to accomplish the reliability of the analysis, discrepancies in the data were also revealed. Moreover, as consistent with the content analysis, the current study utilized basic quantitative calculations to understand some of the data. Accordingly, while the content analysis provided a descriptive approach to the current study in both coding of the data and its interpretation of simple quantitative calculations of the codes (Denzin \& Lincoln, 2000; Downe-Wamboldt, 1992), the thematic analysis provided to the current study a purely qualitative and detailed data (Braun \& Clarke, 2006).

\section{PARTICIPANTS}

It was aimed to examine what difficulties educators experienced in providing distance or face-to-face education following Reggio Emilia approach in the New Normal. Accordingly, all Reggio Emilia-inspired educators in Turkey were invited to participate in this research and fill out the questionnaire voluntarily. However, to participate in this study, the condition of working currently or at least having been worked during the COVID-19 pandemic was sought. Informed voluntary consent was obtained. Confidentiality of all participants in this research was accomplished through concealing the real names, and no identifying information, such as the name of institutions they were working for, was included.

The number of educators in Reggio Emilia-inspired schools in Turkey is not so large and this is the very first research which was conducted on such topic, so the entire universe was invited to participate to be able find a meaningful variation. Billsberry, Ambrosini, Garrido-Lopez, and Stiles (2019) state, "Most phenomenographic studies employ simple and straightforward datagathering and analysis and do not require large data sets." (p. 630) and continue that about 30 participants is "relatively low sample size and apparent simplicity makes the approach appealing, but may lead to skepticism, particularly in relation to how the researcher has determined the structure of conceptions" (p. 630). In the current study, 226 Reggio Emilia-inspired educators participated from 33 cities in Turkey as well as one from Baku, Azerbaijan, and one from Brescia, Italy by completing the questionnaire (see Figure 2).

All of the data that came from volunteer participants in Turkey were included in the study to obtain as much as information from a variety of voices except the ones that came from other countries because the target of the current study was Turkey. However, to be more accurate, the researcher wanted to show that those volunteer participants from other countries were participated in the study. In the future, similar research might be done in Turkey including countries other than Turkey to be able to get a more global understanding of the difficulties that Reggio Emilia-inspired educators had during the COVID-19 pandemic.

The participants, who were all Reggio Emilia-inspired educators, held various positions at schools. They were mostly managers (38), preschool teachers (168) and pedagogistas (8). The rest of the participants was elementary school teachers, physical education teachers, math teachers, atelieristas, program developers, and academics as a parent or an architect. The age group/s of children they worked with are as follows: $9,7 \%$ of the participants worked with children aged between $0-2 ; 32 \%$ of the participants worked with children aged three years; $44,7 \%$ of the participants worked with children aged four years; $60,6 \%$ of the participants worked with children aged five years; $38,5 \%$ of the participants worked with children aged six years; the rest of the participants worked with older children. It is important to note that those educators worked with one or more age groups at the same time, that's why some of the percentages overlap. 


\section{City where you live}

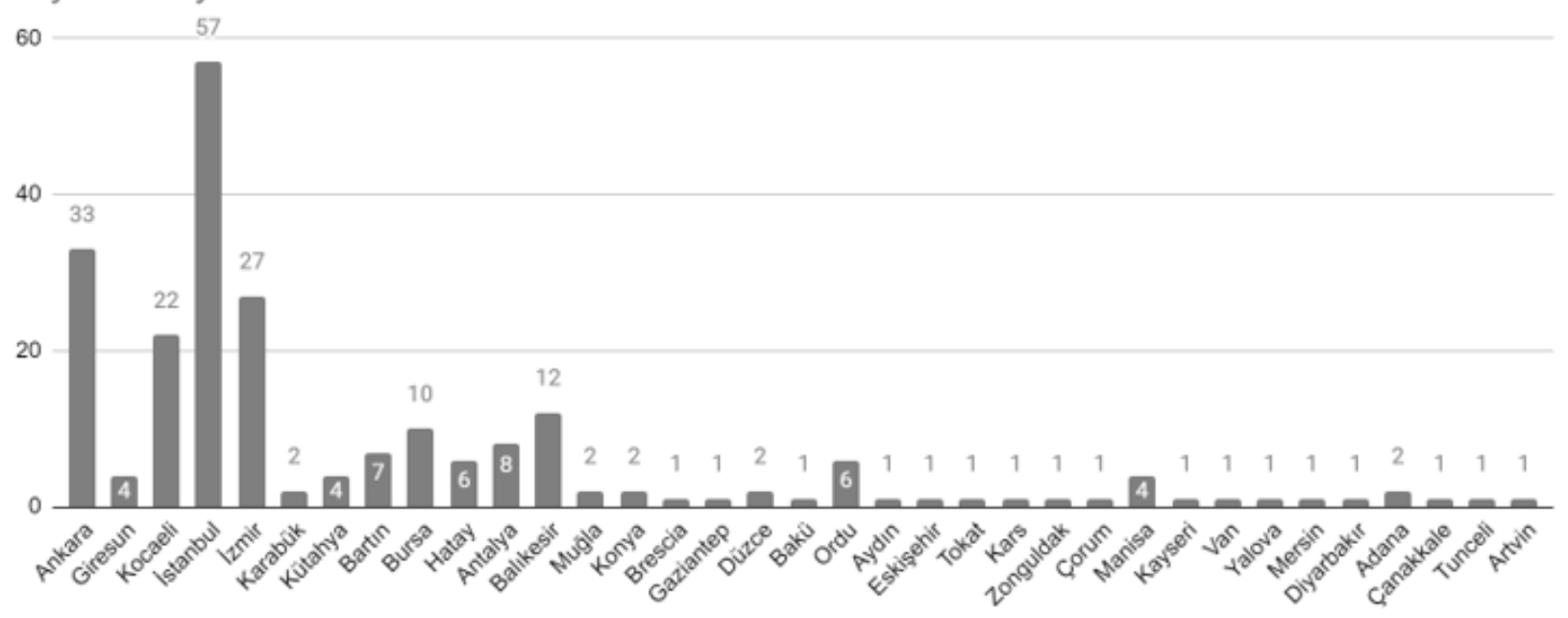

Figure 2. Cities where the participants live

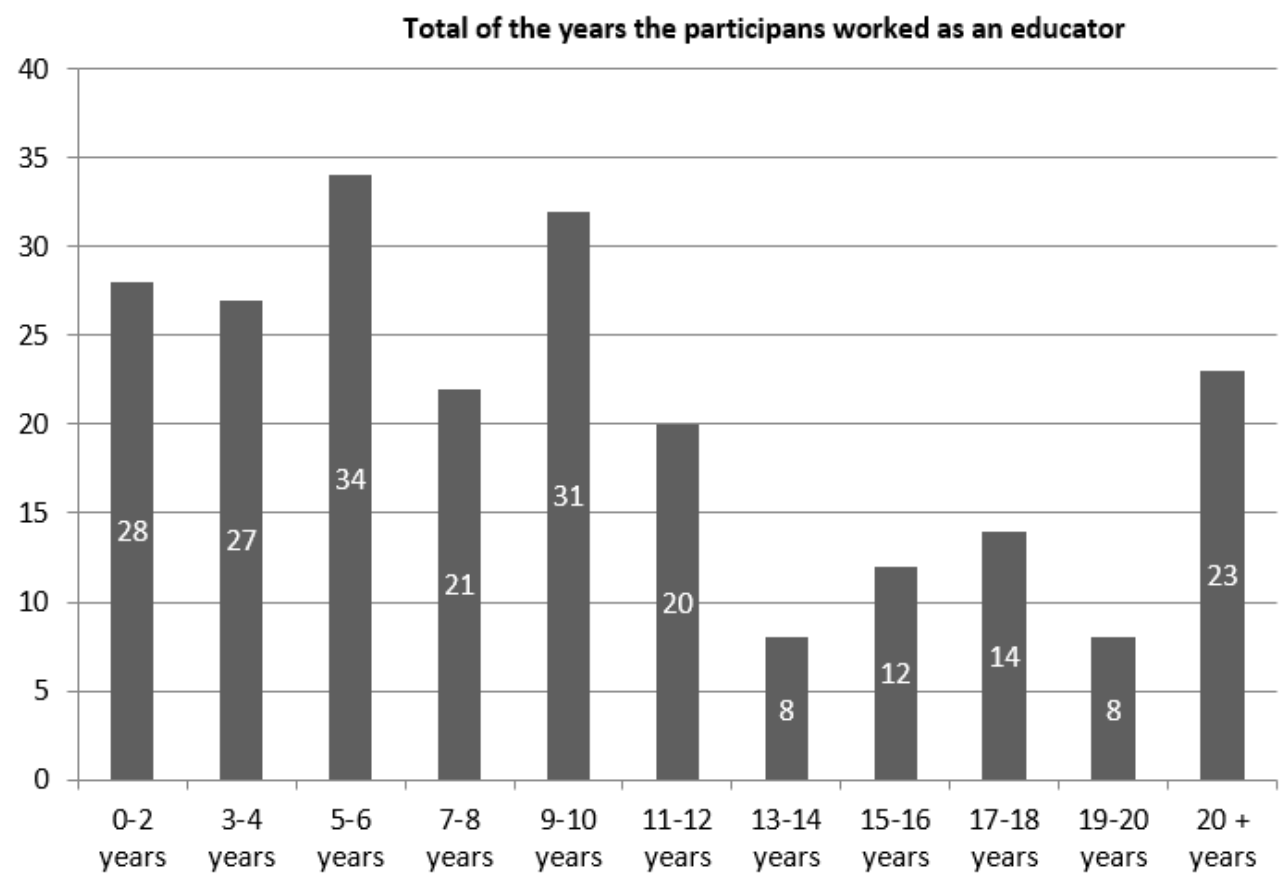

Figure 3. The total of the years 226 participants worked as an educator

Moreover, the total of the years that they worked as an educator is presented in Figure $\mathbf{3}$, and the total of the years that they worked as a Reggio Emilia-inspired educator is presented in Figure 4.

As seen in Figure 3, the total of the years the participants worked as an educator varies a lot between less than a year to more than 20 years. Accordingly, the participants of this research are good representatives in terms of having voices of educators with varying years of experience.

On the other hand, as seen in Figure 4, the total of the years the participants worked as a Reggio Emilia-inspired educator is comparatively short. This is something expected because Reggio Emilia approach is a new coming pedagogy to the education system in Turkey. More than half of the participants (122) had experiences with Reggio Emilia for less than one year.

Lather (1986) states that including a variety of voices is seen as strength of research studies. This is a general principle of qualitative methodologies to be democratic and accurate and to control bias by ensuring the representativeness of a variety of participants (Howe, 2004). Accordingly, it can be said that the participants in the current study were good representatives regarding the cities that they were from, the role they held at the school, the age groups that they worked with, and the varying years of experience as an educator and as a Reggio Emilia-inspired educator. Moreover, Lincoln and Guba (2003) state that all voices in the inquiry effort should have a chance to be represented in the research and to have their stories on the topic treated fairly and with balance. Accordingly, the current research aimed to include as much as voices in the research and treated the data that came from the participants fairly and with balance by including their stories or representing their stories by the themes and the codes in the research without making generalization. Furthermore, the participants provide important information about the profile of Reggio Emilia-inspired educators in Turkey. For example, it shows how prevalent Reggio Emilia is throughout Turkey. 


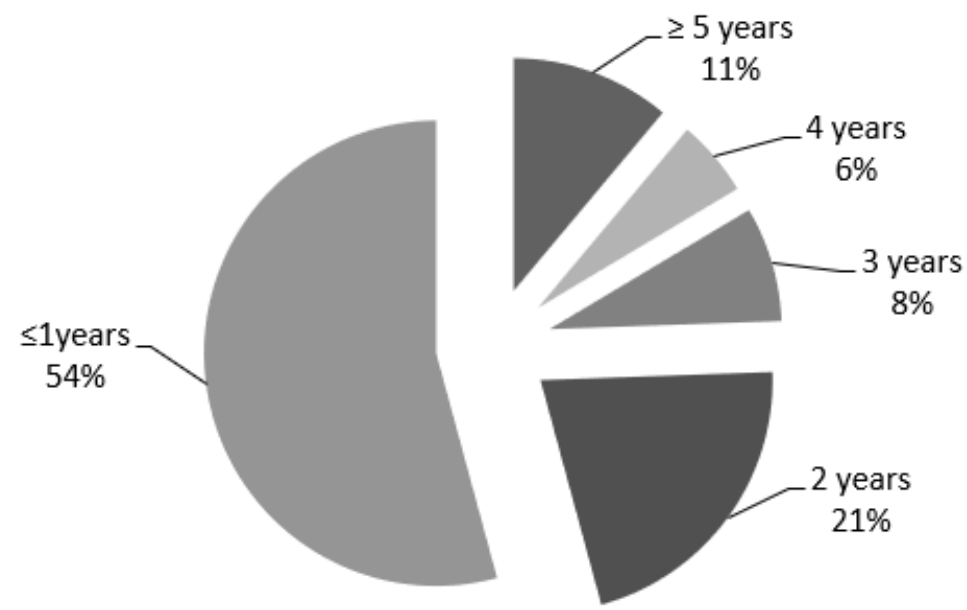

Figure 4. The duration of their experiences as a Reggio Emilia-inspired educator

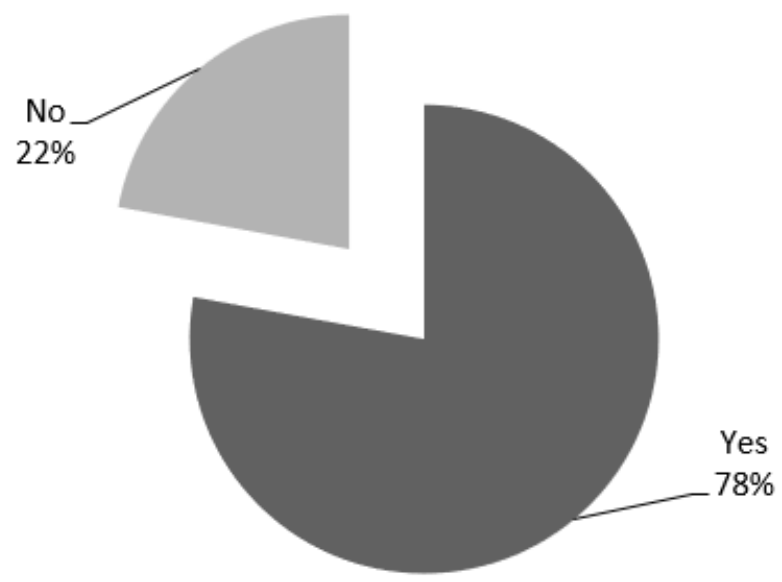

Figure 5. Have you done online or distance education with children in your institution during the pandemic?

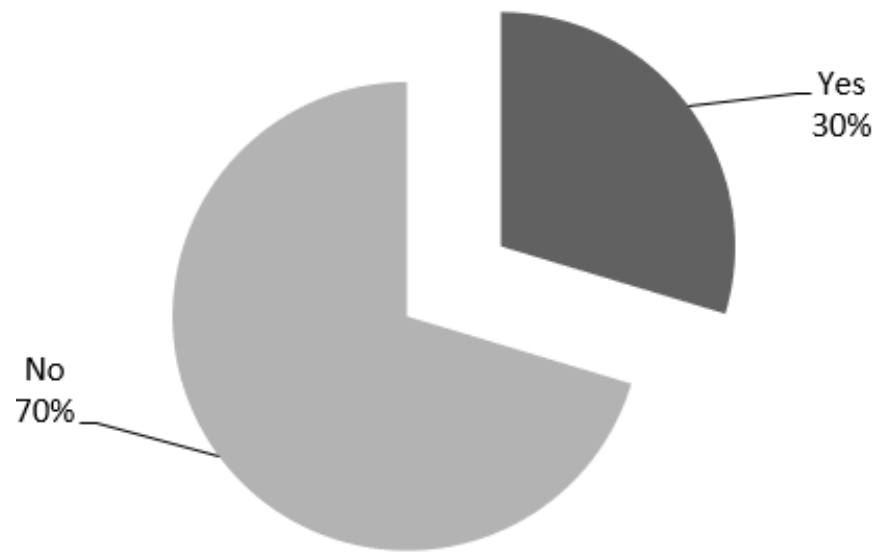

Figure 6. Have you had face-to-face education with children in your institution during the COVID-19 pandemic?

\section{FINDINGS}

The answers of the participants to the question "Have you done online or distance education with children in your institution during the COVID-19 process?" are presented in Figure 5.

The answers of the participants to the question "Have you had face-to-face education with children in your institution during the COVID-19 pandemic?" are presented in Figure 6.

Figure 5 shows that $78 \%$ of the participants did online or distance education with children at their institutions during the pandemic. Figure 6 shows that 30\% of the participants appeared to be doing face-to-face education. It is also essential to note that $7.5 \%$ of the participants did both online/distance and face-to-face education at the same time. Moreover, it is important to 
Table 1. What is your experience of face-to-face education during the pandemic?

\begin{tabular}{|c|c|c|}
\hline The way & How? (Methods) & Example excerpts from answers \\
\hline $\begin{array}{l}\text { Face-to- } \\
\text { face }\end{array}$ & 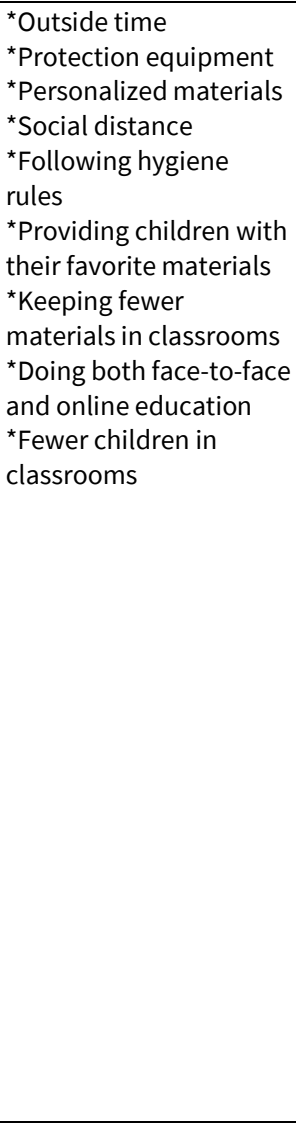 & 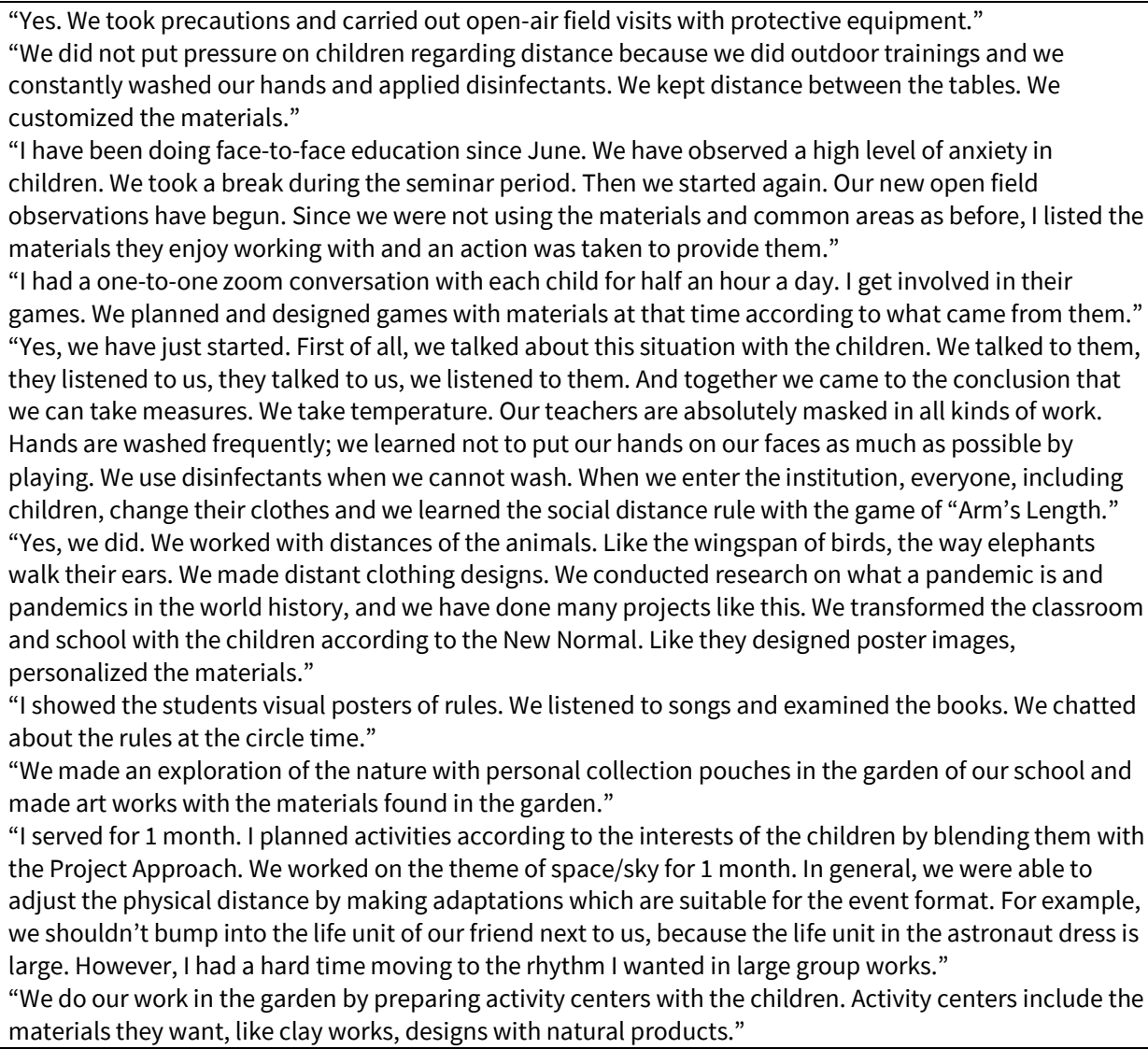 \\
\hline
\end{tabular}

note that among the ones who did online/distance education only 75 out of 176 participants, which is very low ( $33 \%$ of total participants), tried to adapt their online/distance education according to the Reggio Emilia principles. As understood from the data, some of the educators could not continue education during the pandemic or some of them could not provide education according to the principles they believed in, namely Reggio Emilia principles. Education was hindered by the pandemic.

The answers of the participants to the question "Did you do face-to-face education with children in your institution during the COVID-19 pandemic? If yes, please explain in detail how you did face-to-face education following Reggio Emilia approach and how you followed the hygiene/social distance rules." are presented in Table 1.

Table 1 presents many findings about the experiences of educators during the pandemic. The data show that they tried to accomplish one or two of the followings in the New Normal: "More outside time," "Protection equipment," "Personalized materials," "Social distance," "Following hygiene rules," "Providing children their favorite materials," "Keeping fewer materials in the classroom," "Doing both face-to-face and online education at the same time," and "Keeping fewer children in classrooms." The data also show that educators used at least one or two methods, which are stated in Table 1, during face-to-face education. However, all of those methods should be a must for every school. Moreover, there were some other discrepancies in the data. For example, one participant stated, "We could not adapt to constant hand washing, working with a face mask and keeping social distance." However, all of the schools should apply those rules as a must because of the risk of pandemic.

The answers of the participants to the question "If you did online/distance education, what kind of difficulties did you encounter while doing online/distance Reggio Emilia-inspired education?" are presented in Table 2.

Table 2 presents the difficulties encountered by the educators, namely, having no mental involvement of children online because of shorter attention span during early years, less interaction online, a risk of direct instruction (i.e., lecturing) online, bored kids online, technological problems like bad Internet connection, no hands-on education online, limited variety of activities online, and even no physically participation online. However, none of them is related to different ways of distance education other than online education. All of the difficulties stated by the educators are about online education. Educators should learn different ways of distance education in early childhood education to overcome the difficulties of online education as well as effective usage of online tools. 
Table 2. What kind of difficulties did you encounter while doing online/distance Reggio Emilia-inspired education?

\begin{tabular}{|c|c|}
\hline Difficulties in online/distance education & Example excerpts from answers \\
\hline *Short attention span (No mental involvement online) & "As the age group gets smaller, they cannot focus." \\
\hline *Less interaction online & "Yes, I did. I think it's ridiculous." \\
\hline${ }^{\star}$ Risk of direct instruction online & "Sitting in front of the screen and trying to teach (learn) with the classical method is \\
\hline${ }^{\star}$ Bored kids online & boring as well as challenging for children." \\
\hline${ }^{\star}$ Technological problems & "Sound interruptions." \\
\hline${ }^{*}$ No hands-on education online & "Not being able to do projects together, not experimenting together." \\
\hline *Limited variety of activities online & "Students without Internet and computers had a hard time." \\
\hline *No physically involvement online & $\begin{array}{l}\text { "Not being eye to eye with the child, and mostly mothers trying to do the activity } \\
\text { prevented me from achieving the goal that I wanted." } \\
\text { "We were having trouble in producing a content." } \\
\text { "Connection problems, lack of full participation, and sometimes families' lack of } \\
\text { coordination negatively affected the process." }\end{array}$ \\
\hline
\end{tabular}

Table 3. "What kind of difficulties did you experience while doing face-to-face Reggio Emilia-inspired education?"

\begin{tabular}{|c|c|}
\hline Difficulties in face-to-face education & Example excerpts from answers \\
\hline *Fewer materials & “They couldn’t bring a material from home. We could not get guests. We couldn’t take a field trip. “ \\
\hline *No sharing & "We had difficulties because we had little contact with children and we were careful about not using \\
\hline *No field-visiting & common materials for hygiene reasons." \\
\hline${ }^{\star}$ Crowded classrooms & "The crowded classes of mine and the intensity of academic education I gave. Not being able to \\
\hline $\begin{array}{l}\text { *Difficulty in keeping children in front of } \\
\text { the screen }\end{array}$ & $\begin{array}{l}\text { create a time and an environment that will direct and structure the project work and not enabling } \\
\text { children to gain experience." }\end{array}$ \\
\hline *Less physical space & "We had a hard time in getting the kids seated in front of the screen." \\
\hline${ }^{\star}$ No outside time opportunities & "We had a shortage of materials, lack of physical space, not being able to go to nature enough. We \\
\hline${ }^{\star}$ Difficulty in finding tread of interest & did not do (online) education during the time of COVID-19." \\
\hline $\begin{array}{l}\text { *Difficulty in doing documentation } \\
\text { ^Difficulty in doing provocation }\end{array}$ & $\begin{array}{l}\text { "I had trouble in catching the curiosity of the child. I had a hard time in planning the next process of } \\
\text { curiosity and preparing provocation." }\end{array}$ \\
\hline *Difficulty in having both online and face- & "We had the difficulties in being face to face and online at the same time." \\
\hline $\begin{array}{l}\text { to-face education at the same time } \\
\text { ^Back to school/adaptation problems }\end{array}$ & $\begin{array}{l}\text { "We are still in the orientation process with children. They have concerns as if we haven't passed the } \\
\text { last } 1.5 \text { years together." }\end{array}$ \\
\hline *Lack of knowledge in Reggio Emilia & "Not knowing Reggio exactly." \\
\hline approach & "Only with children with specific learning difficulties." \\
\hline${ }^{\star}$ Children with special rights & "I didn't have much difficulty except for the distance." \\
\hline *Social distance & "Project steps." \\
\hline $\begin{array}{l}\text { *Technology addiction } \\
{ }^{\star} \text { Difficulty in doing project-based } \\
\text { education }\end{array}$ & $\begin{array}{l}\text { "When we started doing face-to-face education again, we experienced an adaptation problem in all } \\
\text { age groups. The children had technological crises frequently during the day and they asked us for } \\
\text { tablets and phones. After } 3 \text { months, they returned as more adult addicted children." }\end{array}$ \\
\hline
\end{tabular}

The answers of the participants to the question "What kind of difficulties did you experience while doing face-to-face Reggio Emilia-inspired education?" are presented in Table 3.

Although most of the participants complained about having difficulties in online/distance education, comparatively fewer participants complained about difficulties they experienced during face-to-face education. Although the researcher predicted to see more problems in project development as it usually takes place in pairs or groups, the problems of the participants ranged from having insufficient materials and space inside and outside the school to adaption problems after the long break. More specifically, it is found that educators had difficulties in conducting face-to-face education because of having fewer materials in classrooms as a result of removing materials from the school for hygiene reasons, crowded classrooms, less physical space in classrooms, no sharing allowed among children, no outside time or field-visit opportunities any more, and back to school problems after lock-down (i.e., being technology addicted during the lock-down and asking for tablets or phones at school all the time, or hardly adapting to school). It is also found that they had difficulties in keeping children in front of the screen in the classroom, finding tread of interest to start projects, doing documentation and provocation as musts of Reggio Emilia approach, working children with special rights (i.e., children with special needs), doing project-based education, keeping social distance in the school, and having both online and face-to-face education at the same time. Moreover, some of the participants stated that they had lack of knowledge on Reggio Emilia approach itself and that's why they were having difficulty in doing face-to-face education effectively.

The answers of the participants to the question "Do you think that education was effective for children during the pandemic? What is your experience of effective face-to-face and online/distance education during the pandemic?" are presented in Table 4. 
Table 4. Do you think that education was effective during the pandemic? What is your experience of effective face-to-face and online/distance education during the pandemic?

\begin{tabular}{|c|c|}
\hline The way & Example excerpts from answers \\
\hline Effective: & "I think, yes, because children are washing their hands properly every time they get \\
\hline${ }^{\star}$ Supported individual work & into line and go to the playground." \\
\hline *Supported self-regulation & "I think that it is effective because we are moving towards online education system \\
\hline *Supported child image, who is creative thinker & gradually and I find online education efficient in terms of creating processes that are \\
\hline${ }^{\star}$ Supported active learning & more adaptable and sustainable." \\
\hline${ }^{\star}$ Reggio changed our understanding of ECE & "Any kind of education contributes learning." \\
\hline${ }^{\star}$ Supported professional development & "I think that online education is not effective for young children at all." \\
\hline *Supported asking questions & "No. We could not live the team spirit side by side, as unity." \\
\hline $\begin{array}{l}\text { *Supported learning with nature, technology and home } \\
\text { materials }\end{array}$ & $\begin{array}{l}\text { "We did not do it face to face, and online education was not effective because we } \\
\text { could not reach everyone and we could not apply the Reggio education model." }\end{array}$ \\
\hline${ }^{\star}$ Supported child-centered education & "I do not think that online education provides teachers an opportunity to observe \\
\hline *Supported new types of education & and listen to children pedagogically. Therefore, I do not think that online education \\
\hline *Supported learning in any way & is effective. " \\
\hline Not effective: & $\begin{array}{l}\text { "It was not very effective due to the children being young, being active, Internet } \\
\text { freezing constantly, and sound quality being poor." }\end{array}$ \\
\hline${ }^{\star}$ No community of learning online & "I think that teachers should constantly update themselves. The world is changing \\
\hline *Not much interaction online & every moment and the information should be renewed and kept up with the time." \\
\hline${ }^{\star}$ Not much pedagogical listening/documentation online & "Yes, but it worries me that teachers are at risk" \\
\hline *Bad technology & "We have observed high levels of anxiety in children." \\
\hline \multicolumn{2}{|l|}{ *No being inspired by Reggio sufficiently } \\
\hline${ }^{\star}$ Being afraid of getting infected & \\
\hline
\end{tabular}

Table 5. Did the parents support you during this process? Did others support you during this process? How and who?

\begin{tabular}{|c|c|c|}
\hline & How? & Example excerpts from answers \\
\hline Parent supports & $\begin{array}{l}\text { *No support } \\
{ }^{\star} \text { Materials } \\
\text { *Educational support } \\
{ }^{\star} \text { Technical support } \\
\text { *Hygiene }\end{array}$ & $\begin{array}{l}\text { "No." } \\
\text { "They provided sterile material." } \\
\text { "They shared the activities with us as a feedback and they cared about it." } \\
\text { "We didn't get much support from parents in this process. Their expectations were a } \\
\text { more classic/traditional education." } \\
\text { "They provided technical support." } \\
\text { "They supported us. Especially with the hygiene rules. Brought the items after } \\
\text { disinfecting them first. Took precautions even when the children got a runny nose. } \\
\text { Helped us a lot." }\end{array}$ \\
\hline Other supports & $\begin{array}{l}{ }^{\star} \text { No support } \\
{ }^{\star} \text { Other educators in the school } \\
{ }^{\star} \text { Educational networks } \\
{ }^{\star} \text { Experts } \\
{ }^{\star} \text { Own family } \\
{ }^{\star} \text { Child's other relatives } \\
{ }^{\star} \text { Online educational supports }\end{array}$ & $\begin{array}{l}\text { "School staff tried to support." } \\
\text { "The Education Reform Initiative and the teacher network have provided studies and } \\
\text { reports." } \\
\text { "I got support from subject matter experts, the school administration, my own family } \\
\text { and children's families." } \\
\text { "Grandmothers, grandfathers, aunts. They were all great." } \\
\text { "We received a lot of training online" }\end{array}$ \\
\hline
\end{tabular}

The answers of the participants to the question on effectiveness of education during the pandemic did not vary much (Table 4). Most agreed that face-to-face education during the pandemic was effective in supporting children's development and learning but online education was not effective in supporting children's development and learning. They also added another difficulty they experienced during online/distance education: Not much pedagogical listening/documentation online. Only a few agreed that online/distance education was effective in some ways, such as increasing children's self-regulation skills. Moreover, although most of the educators thought face-to-face education to be effective during the pandemic, they were worried about their health during the pandemic (i.e., getting infected by coronavirus).

The answers of the participants to the question "Did the parents support you during this process? Did others support you during this process? How and who? Please explain." are presented in Table $\mathbf{5}$.

It is found that some of the participants faced difficulties all by themselves while some of them were lucky in terms of getting support in various ways, such as getting education about the new education system.

The answers of the participants to the question "For what age groups do you think online/distance education is suitable?" are presented in Figure 7.

Most of the participants think that online/distance education is suitable for children aged 6 and up. 


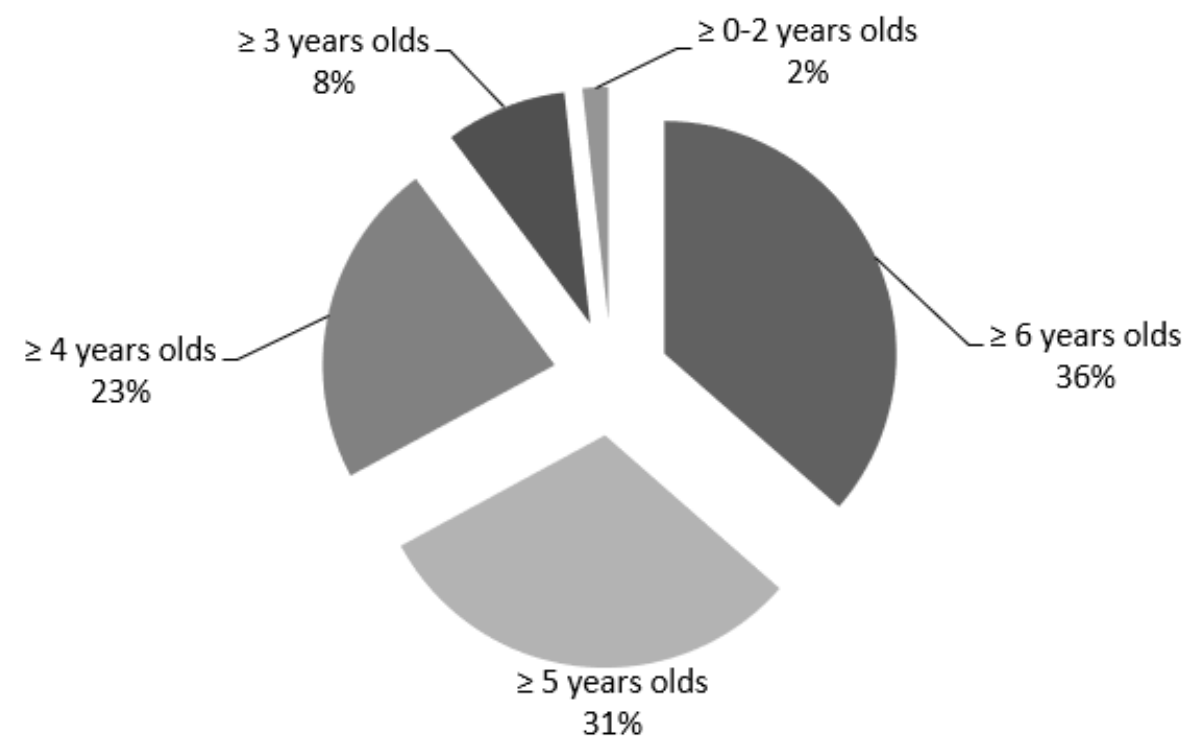

Figure 7. For what age groups do you think online/distance education is suitable?

\section{DISCUSSION}

The current research involved 226 Reggio Emilia-inspired educators from 33 cities of Turkey. The participants, who were all Reggio Emilia-inspired, had various roles as an educator, namely school managers, preschool teachers, pedagogistas, elementary school teachers, physical education teachers, math teachers, academics as an architect or a parent, atelieristas, and program developers. Most of them focused on preschool ages while a few of them focused on the early ages of elementary school years. In short, all focused on early childhood years. The participants ranged between less experienced educators to 33 years of experienced educators. On the other hand, the total of the years the participants worked as a Reggio Emilia-inspired educator was comparatively very short. Accordingly, the participants were good representatives of the Reggio Emilia-inspired educators in Turkey to be able raise their voices.

As many educators stated that the first aim during the pandemic was to stay with children instead of giving online instruction, "As early childhood educators, we must build and maintain close relationships with children and their families." stated by DiCarlo and Fazio-Brunson (2020, p. 64). DiCarlo and Fazio-Brunson continued, "We advised our families to create a low stress environment, establish and maintain a routine, stay socially connected. With family and friends, create learning opportunities within daily tasks and focus on the positive." (p. 64-65). Accordingly, it was good that $78 \%$ of educators participated in the current research worked hard to stay in touch with children and their families through online tools. On the other hand, they had many difficulties in providing both online/distance education and face-to-face education respectively during the pandemic.

Wasmuth (2020) states, "Young children are in danger of becoming collateral damage in the COVID19 pandemic. Institutions of Early Childhood Education and Care (ECEC) are closed and so are playgrounds, libraries and museums. Even play dates are out. Thus, young children are deprived of necessary social interactions." (p. 87). Parallel to the results of this research, the current research revealed that both public and private school educators suffered from difficulties in conducting online/distance education, such as less or no interaction through the screen. However, only a few of them agreed that online education was effective in supporting children's development and learning, (i.e., increasing children's self-regulation skills, individual work, active learning, and learning with nature, technology and home materials) while all agreed that face-to-face education was effective in supporting children's development and learning. Most of them stated varying difficulties and negative experiences of online education because of "Short attention span of young children," "Less interaction online," "More direct instruction/lecturing online," "Bored kids online," "Technological problems," "No hands-on education online," "Limited activities online," and "No actual involvement online." None of the difficulties stated by the participants is related to the other ways of distance education, but all of the difficulties stated are about online education. Actually, participants thought that online/distance education is suitable for children aged 6 and up. More specifically, 36\% of the participants believe in 6 years and up, 30.5\% of the participants believe in 5 years and up, $22.5 \%$ of the participants believe in 4 years and up, $8.4 \%$ of the participants believe in 3 years and up, and only $1.8 \%$ of the participants believe in that $0-2$ years and up ages. The question "What is appropriate for young children regarding their education?" should be asked as well as "How do educators overcome difficulties in the New Normal?" Accordingly, educators should learn different ways of distance education as well as online education techniques like gamification (Samur, 2019) in early childhood to overcome the difficulties and handicaps of online education (e.g., limited attention span of young children, limited time for screen exposure and limited effectiveness of screen exposure in development of $21^{\text {st }}$ century skills) and to provide more developmentally appropriate education (Copple \& Bredekamp, 1987, 2009; Reimers \& Schleicher, 2020; WHO, 2019).

Young children need adult supervision and support while learning and they need to mentally and physically participate in activities so that they can enjoy and learn (Rankin, 2004). And that is only possible when they interact with materials and others in small groups. Otherwise, they get bored and lose their interest in the topic. The research conducted by Atmaca and Başbay (2020) 
shows that small group activities in a Reggio Emilia-inspired school provide children with the ability to listen to others, get others to listen to them, and communicate in some other ways. However, the current study shows that online education given by the participants did not support any kind of group work and children had difficulty in paying attention to the topic. In the current study, some of the educators could not continue education during the pandemic or some of them could not provide education according to the principles they believed in, namely Reggio Emilia principles. Education was hindered by the pandemic.

Parallel to the findings of the current research about "technological problems" and "no actual involvement online" that disadvantaged families and children experienced, the Scottish Government Learning Directorate (2020) stressed that disadvantaged children and families require particular consideration during the pandemic because they are more at risk than ever. However, interestingly, only a few educators in the current research stated their concerns and worries about children at risk and children with special needs/rights, such as bad internet connection. Accordingly, the socio-economic status of families was so apparent during the pandemic in terms of the education of young children (Giannini \& Grant Lewis, 2020; Reimers \& Schleicher, 2020; UNESCO, 2020). Similar research findings are found across the world for disadvantaged groups as a result of the social injustice and the misdistribution of money, power, and resources (Xafis, 2020) thus an action is needed to provide better education for young children at risk. It is not possible for educators to resolve technological problems like bad/no Internet connection or lack of technological equipment at home but they can make use of another way to conduct distance education as stated in Coldeway's (1986) Quadrants, such as "students and the teacher are in the same place at different times" or "students and the teacher are in different places at different times" instead of sticking to only online education in which "students and the teacher are in different places at the same time."

After passing the first months in which "urgent online education" was done, it was a must to conduct research on such difficulties and then look for solutions. Parallel to this idea, Louis-Jean and Cenat (2020) state, "This could intrinsically require educators to work with educational technology companies to figure out and develop the best instructional designs to make the best out of e-learning." (p. 3). Similarly, Tria (2020), a researcher in Philippines, states, "Future studies are recommended such as planning and implementation strategy, assessing online learning systems to schools, a survey on online platforms, project proposals and capstone projects, program creation, community assessment, revision of curricula, development of instructional materials and many more." (p. 3). It is clear that actions need to be taken on education practices. The current research shows that participants were happy to learn new types of education, work on their professional development, and be more knowledgeable about Reggio Emilia, which changed their understanding of early childhood education. They even stated that although education in the New Normal was challenging for them and the children, it was effective in terms of supporting their learning in any way.

The findings of the current research showed that some of the participants did face-to-face education after June 2020 through September 2020. It is found that educators and children used different methods/ways during those extraordinary times because of the pandemic. More specifically, they tried to do more frequent outside time than before because they believed that to have classes in open air is less risky during the pandemic. They started using protection equipment like face masks and keeping social distance to protect each other from spreading and getting coronavirus. They started using personalized materials instead of sharing materials. They started following hygiene rules in the school from hand-washing to keeping affected people away from the school and had fewer children in each classroom to have larger social distance. They removed risky or unnecessary materials from the school to have fewer materials in classrooms but provided children with their favorite materials. Similar measures have been taken in other countries to prevent the virus from spreading (Esposito, \& Principi, 2020). Some of the participants did not only do face-to-face education but they used mixed education. In other words, $7.5 \%$ of the participants did both online/distance and face-to-face education at the same time and found it difficult to accomplish. Moreover, an educator stated, "We could not adapt to constant hand washing, working with a face mask and social distance." However, all precautions should be included while handling education face-to-face according to the new regulations (Inan, 2020; MEB, 2020).

Reggio Emilia-inspired educators participating in the current research stated that they encountered the following difficulties in face-to-face education: "Fewer materials," "No sharing allowed," "No field-visits," "Crowded classrooms," "Difficulty in keeping children in front of the screen," "Less space for each child," "No outside opportunities, like a garden," "Difficulty in finding tread of interest," "Difficulty in keeping documentation," "No ideas for provocation," "Having both online and face-to-face education at the same time," "Back to school/adaptation problems," "Lack of knowledge in Reggio Emilia approach," "Lack of support for children with special rights," "Having difficulty in keeping social distance," "Technology addiction in children after frequent use of online education" as well as having difficulty in conducting "Project-based education." It is important to stress that there is no need for keeping children in front of the screen at school because they have already been exposed to the screen at home too much during the pandemic. Actually, it is better to keep children active instead of passive at school.

While most of the participants complained about difficulties they experienced during online/distance education, a comparatively fewer participants complained about difficulties they experienced in face-to-face education because of the COVID19 pandemic. During face-to-face education, their problems focused on a wide range of scope, from having insufficient materials and space inside and outside the school to adaption problems to school after the long break because of the pandemic. However, it is interesting that some of the participants complained about some difficulties which are not related to the COVID-19 pandemic, namely, having difficulty in finding tread of interest, doing documentation and provocation, having lack of knowledge about Reggio Emilia in general and in education of children with special rights. In fact, as more than half (122) of the participants had less than a year of experience with Reggio Emilia, the challenges they faced may not be due to the COVID-19 pandemic, but simply from their low experience in Reggio Emilia approach.

Finally, while some of the participants stated that they did not have any support from families at all, some received both parental support - in terms of "Materials," "Educational support," "Technical support," and "Hygiene," - and others' support, namely support from "Other educators in the school," "Educational networks," "Experts," "Own family," "Child's other relatives," 
and "Online educational supports." Rasmitadila et al. (2020) researched in Indonesia and stressed the importance of support from all stakeholders in the education of young children, namely, government, schools, teachers, parents, and the community. However, the participant educators in the current study stated that the only support providers for them were their school, children's and their own families, and some volunteer/paid networks.

\section{CONCLUSION}

Reggio Emilia-inspired educators in Turkey had both technical and educational difficulties in conducting distance and faceto-face education effectively during the COVID-19 pandemic while some of them could not continue education at all. They were cognizant of new necessities that the New Normal has brought and open to professional development opportunities to adapt to the new world. Some were lucky to get support from outside for both professional development and personal issues during the pandemic while some were afraid of the coronaviruses and felt all alone being not a part of community of learning any more. However, the emergency has passed and people are ready to dig into reconceptualization of both distance education and face-toface education in the New Normal. It is time to rethink about what we did in the past and make a plan for the present and the future. For example, educators should realize that online education (i.e., synchronous) is not the only way of conducting distance education (Berge \& Mrozowski, 2001; Coldeway, 1986) but there are other types of distance education, which are more developmentally appropriate for young children and more inclusive for children at risk. Educators need to be more creative than before and look for new ways of teaching and learning. Parallel to the findings of the current research, Louis-Jean and Cenat (2020) and Tria (2020) state that educators need to work on revision of curricula and new educational materials/strategies to overcome the obstacles that occurred in the New Normal.

Similarly, in many countries like China and Georgia, schools are deploying innovative and renewed approaches in restructuring education (Basilaia \& Kvavadze, 2020; Zhu \& Liu, 2020). Vintimilla and Pacini-Ketchabaw (2020) state, during the COVID-19 pandemic "within the context of early education, pedagogy has become an obscure, sophisticated supplement of some sort rather than an indeterminate field of responsive, generative, and collaborative practice of interpretation, ethical critique, and invention." (p. 628). Accordingly, education needs to be reconceptualized in the New Normal. There is a possibility of that the whole concept of education and care might change and early childhood education might be restructured in the New Normal abandoning the questionable parts of the current education system in Turkey. As stated by Wasmuth (2020),

"The thinking briefly outlined here - and the example of considering the child as an absolute other is only one of the numerous possibilities - would mean a huge shift in ECEC. However, such a utopia is needed. It is needed not only because past practices in ECEC have been harmful to too many young children, but also because the present crisis offers the opportunity for ECEC practitioners and philosophers to rethink what it means to educate and care for young children. It is the chance to find a genuine voice to not only to describe, analyse and defend the field of ECEC, but also to advocate for young children as absolute Others." (p. 93).

Accordingly, in the New Normal, before restructuring education in Turkey, educators should answer the following five questions of early childhood education and care:

1- What should be given?

2- Why should it be given?

3- How should it be given?

4- To whom should it be given?

5- When should it be given?

As stated by Mutton (2020), "What is fascinating in this collection of papers, however, is the way in which so many teacher educators internationally have seen the current crisis as an opportunity to consider new ways of working, to adopt innovative approaches to pedagogy and to re-conceptualise the nature of their teacher education programmes" (p. n/a). Accordingly, educators should see the New Normal as a chance to rebuild early childhood education in Turkey upon more humanistic, more child-centered, more child-friendly, more freedom-oriented, more scientific evidence-based, more interest-based and more inquiry-based practices but less-directed and less-stressful practices. The importance of Reggio Emilia pedagogy has become more apparent during the pandemic because many of the necessities that occurred during the pandemic have already existed in Reggio Emilia. For example, children are used to working in small groups or by themselves without getting much help from the teacher and others. They use all parts of the school like patio/playground/garden/classroom/piazzas and ateliers being not close to each other. Moreover, they are used to deciding on what to do and how to do something so that they can work even at home independently and creatively and so on. It is an urgent need for Reggio Emilia-inspired educators in Turkey to get together and cothink on Reggio Emilia approach and practices to be inspired.

\section{SUGGESTIONS}

Based on the findings of this research, the following suggestions are developed for the participants: 
1- Reggio Emilia-inspired educators should find theoretical solutions to the problems they experience and reconstruct their understanding of education in the New Normal. Because being Reggio Emilia-inspired means not copying educational materials of others but creating original projects based on the needs and interests of their school.

2- Reggio Emilia-inspired educators should check what Reggio Emilia teachers in Italy do in the New Normal so that they can see examples of projects and then create their own.

3- Reggio Emilia-inspired educators should work on both distance and face-to-face educational practices. Although education is face-to-face nowadays, the world might need to be shut down again because of the pandemic or another reason. It is necessary to be ready for online/distance education in case of emergencies that might occur again. Educators should learn different ways of distance education other than online education.

4- In fact, as many of the participants had less than a year of experience with Reggio Emilia, the challenges they faced may not be due to the pandemic, but simply from their low experience in Reggio Emilia approach, which is a new coming pedagogy to Turkey. Accordingly, they should also study Reggio Emilia pedagogy, not just the pedagogy in the New Normal.

5- Some educators stated that they are at risk because of the pandemic. It is essential to pay them what they worth, take measures to protect each other from spreading and getting coronavirus and keep social distancing and practicing coughing/sneezing etiquette.

\section{REFERENCES}

Allvin, R. E. (2020). Making connections. Build it better: Child care after the COVID-19 pandemic. Young Children, 75(3), 62-68.

Atmaca, E., \& Başbay, M. (2020). Investigation of first year practices in a primary school inspired by the Reggio Emilia Approach. In Y. Günaydin \& F. Ünal Bozdağ (Eds.), Current Researches in Educational Sciences I/ (Chapter 10, pp. 120-168). Ankara: Akademisyen Bookstore.

Basilaia, G., \& Kvavadze, D. (2020). Transition to online education in schools during a SARS-CoV-2 Coronavirus (COVID-19) pandemic in Georgia. Pedagogical Research, 5(4), em0060. https://doi.org/10.29333/pr/7937

Berge, Z. L., \& Mrozowski, S. (2001). Review of research in distance education, 1990 to 1999. American Journal of Distance Education, 15(3), 5-19. https://doi.org/10.1080/08923640109527090

Billsberry, J., Ambrosini, V., Garrido-Lopez, M., \& Stiles, D. (2019). Toward a non-essentialist approach to management education: Philosophical underpinnings from phenomenography. Academy of Management Learning \& Education, 18(4), 626-638. https://doi.org/10.5465/amle.2017.0401

Braun, V., \& Clarke, V. (2006). Using thematic analysis in psychology. Qualitative Research in Psychology, 3(2), 77-101. https://doi.org/10.1191/1478088706qp063oa

Cockcroft, M. (2020). Screen time to the rescue: Created out of necessity, virtual early learning programming has many upsides. School Library Journal, July, 20-23.

Coldeway, D. O. (1986). Learner characteristics and success. In I. Mugridge \& D. Kaufman (Eds.), Distance Education in Canada (pp. 81-87). London: Croom Helm.

Copple, C., \& Bredekamp, S. (1987). Developmentally Appropriate Practice in Early Childhood Programs Serving Children from Birth through Age 8. Washington, DC: NAEYC.

Copple, C., \& Bredekamp, S. (2009). Developmentally Appropriate Practice in Early Childhood Programs Serving Children from Birth through Age 8 (3rd ed.). Washington, DC: NAEYC.

Denzin, N. K., \& Lincoln, Y. S. (2000). Handbook of Qualitative Research (2nd ed.). London: Sage Publications.

DiCarlo, C. F., \& Fazio-Brunson, M. (2020). Navigating quarantine with young children. Child Care Exchange, September/October, 64-67.

Downe-Wamboldt, B. (1992). Content analysis: Methods, applications, and issues. Health Care for Women International, 13(3), 313321. https://doi.org/10.1080/07399339209516006

El Survey Report. (2020). COVID-19 and education: How education unions are responding. 14 to 19 Learning \& Skills Bulletin, 332.

Esposito, S., \& Principi, N. (2020). School closure during the coronavirus disease 2019 (COVID-19) pandemic: An effective intervention at the global level? JAMA Pediatrics, 174(10), 921-922. https://doi.org/10.1001/jamapediatrics.2020.1892

Ferdig, R. E., Baumgartner, E., Hartshorne, R., Kaplan-Rakowski, R., \& Mouza, C. (Eds). (2020). Teaching, technology, and teacher education during the COVID-19 pandemic: Stories from the field. Association for the Advancement of Computing in Education (AACE). Retrieved on 11 September 2020 from https://www.learntechlib.org/p/216903/

Fraga, L. M. (2020). ECE is essential: Advocating for child care during and after a pandemic. Child Care Exchange, July/August, 8-10.

Giannini, S., \& Grant Lewis, S. (2020). Three ways to plan for equity during the school closures. Retrieved on 14 June 2020 from https://gemreportunesco.wordpress.com/2020/03/25/three-ways-to-plan-for-equity-during-the-coronavirus-schoolclosures/

Howe, K. R. (2004). A critique of experimentalism. Qualitative Inquiry: QI, 10(1), 42-61. https://doi.org/10.1177/1077800403259491 
İnan, H. Z. (accepted for publication in 2020). Restructuring early childhood education during the COVID-19 pandemic [COVID-19 pandemi sürecinde okul öncesi eğitimin yeniden yapılandırılması]. Milli Eğitim Dergisi-Journal of National Education, (Special Volume).

Lather, P. (1986). Research as praxis. Harvard Educational Review, 56(3), $257-277$. https://doi.org/10.17763/haer.56.3.bj2h231877069482

Lincoln, Y. S., \& Guba, E. G. (2003). Paradigmatic controversies, contradictions, and emerging confluences. In N. K. Denzin \& Y. S. Lincoln (Eds.), The Landscape of Qualitative Research: Theories and Issues (2nd ed., pp. 253-291). California: SAGE.

Louis-Jean, J., \& Cenat, K. (2020). Beyond the face-to-face learning: A contextual analysis. Pedagogical Research, 5(4), em0077. https://doi.org/10.29333/pr/8466

Marton, F. (1994). Phenomenography. In T. Husein \& T. N. Postlethwaite (Eds.), The International Encyclopedia of Education (2nd ed., Vol. 8, pp. 4424-4429). NY: Pergamon.

McClain Terrell, A. (2020). Taking care of ourselves first. Young Children, 75(3), 56-60.

MEB (Milli Ĕgitim Bakanlığı-Ministry of Education). (2020). Kreşlerde, gündüz bakımevlerinde ve okul öncesi eğitim kurumlarında alınması gereken önlemler [Measures to be taken in kindergartens, day care centers and pre-school education institutions]. Chapter 43. COVID-19 salgın yönetimi ve çalışma rehberi [COVID-19 outbreak management and study guide], 209-216. Retrieved on 12 June 2020 from https://covid19bilgi.saglik.gov.tr/tr/salgin-yonetimi-ve-calisma-rehberi.html

Mutton, T. (2020). Teacher education and COVID-19: Responses and opportunities for new pedagogical initiatives. Journal of Education for Teaching. Published online: 19 Aug 2020. https://doi.org/10.1080/02607476.2020.1805189

Mutua, S. N., \& Ong'ong'a, D. O. (2020). Online news media framing of COVID-19 pandemic: Probing the initial phases of the disease outbreak in international media. European Journal of Interactive Multimedia and Education, 1(2), e02006. https://doi.org/10.30935/ejimed/8402

OMEP. (2020). OMEP Position paper: Early childhood education and care in the time of COVID-19. International Journal of Early Childhood, 52, 119-128. https://doi.org/10.1007/s13158-020-00273-5

Pawilen, G. T. (2020). What do kindergarten children need to know about COVID-19 Pandemic? A supplementary curriculum for Filipino young children during the period of enhanced community quarantine. Asia-Pacific Journal of Research in Early Childhood, 14(3), 23-44. https://doi.org/10.17206/apjrece.2020.14.3.23

Pramling Samuelsson, I., Wagner, J. T., \& Eriksen, Ø. (2020). The coronavirus pandemic and lessons learned in preschools in Norway, Sweden and the United States: OMEP Policy Forum. International Journal of Early Childhood, 52, $129-144$. https://doi.org/10.1007/s13158-020-00267-3

Rankin, B. (2004). Dewey, Piaget, Vygotsky: Connections with Malaguzzi and the Reggio Emilia approach. In J. Hendrick (Ed.), Next Steps toward Teaching the Reggio Way: Accepting the Challenge to Change (2nd ed., pp. 27-36). Upper Saddle River, N.J.: Pearson/Merrill/Prentice Hall.

Rasmitadila, R., Aliyyah, R. R., Rachmadtullah, R., Samsudin, A., Syaodih, E., Nurtanto, M., \& Tambunan, A. R. S. (2020). The perceptions of primary school teachers of online learning during the COVID-19 pandemic period: A case study in Indonesia. Journal of Ethnic and Cultural Studies, 7(2), 90-109. https://doi.org/10.29333/ejecs/388

Reimers, F. M., \& Schleicher, A. (2020). A framework to guide an education response to the COVID-19 Pandemic of 2020. OECD. Retrieved on 12 June 2020 from https://www.hm.ee/sites/default/files/framework_guide_v1_002_harward.pdf

Samur, Y. (2019). Kes Sesi: A mobile game designed to improve kindergarteners' recognition of letter sounds. Journal of Computer Assisted Learning, 35(2), 294-304. https://doi.org/10.1111/jcal.12331

Scottish Government Learning Directorate. (2020). Physical distancing in early learning and childcare settings physical distancing in early learning and childcare settings (ELC), a paper from the COVID-19, Advisory Subgroup on Education and Children's Issues. Educational Journal, 422, 28-36.

Tria, J. Z. (2020). The COVID-19 pandemic through the lens of education in the Philippines: The new normal. International Journal of Pedagogical Development and Lifelong Learning, 1(1), ep2001. https://doi.org/10.30935/ijpdll/8311

UNESCO. (2020). 10 recommendations to plan distance learning solutions. Retrieved on 13 June 2020 from https://en.unesco.org/news/covid-19-10-recommendations-plan-distance-learning-solutions

Varea, V., \& González-Calvo, G. (2020). Touchless classes and absent bodies: Teaching physical education in times of COVID-19. Sport, Education and Society, pp. n/a. https://doi.org/10.1080/13573322.2020.1791814

Vintimilla, C. D., \& Pacini-Ketchabaw, V. (2020). Weaving pedagogy in early childhood education: on openings and their foreclosure. European Early Childhood Education Research Journal, 28(5), 628-641. https://doi.org/10.1080/1350293X.2020.1817235

Wasmuth, H. (2020). Early childhood education and care in a post-pandemic world: The possibility of reimaging the child as another. Knowledge Cultures, 8(2), 87-95. https://doi.org/10.22381/KC82202012

Webb, G. (1997). Deconstructing deep and surface: Towards a critique of phenomenography. Higher Education, 33(2), $195-212$.

WHO (World Health Organization). (2019). Guidelines on physical activity, sedentary behaviour and sleep for children under 5 years of age. World Health Organization. Retrieved on 13 June 2020 from https://apps.who.int/iris/handle/10665/311664

Xafis, V. (2020). 'What is inconvenient for you is life-saving for me': How health inequities are playing out during the COVID-19 pandemic. Asian Bioethics Review, 12(2), 223-234. https://doi.org/10.1007/s41649-020-00119-1 
Zhu, X., \& Liu, J. (2020). Education in and after COVID-19: Immediate responses and long-term visions. Postdigital Science and Education, 2, 695-699. https://doi.org/10.1007/s42438-020-00126-3 